\title{
GAMBARAN ORAL HABIT PADA MURID SD KATOLIK II ST. ANTONIUS PALU
}

\author{
${ }^{1}$ Aves A. Septuaginta \\ ${ }^{2}$ Billy J. Kepel \\ ${ }^{3}$ P. S. Anindita
}

\author{
${ }^{1}$ Kandidat Skripsi Program Studi Kedokteran Gigi Fakultas Kedokteran \\ Universitas Sam Ratulangi Manado \\ ${ }^{2}$ Program Studi Kedokteran Umum Fakultas Kedokteran \\ Universitas Sam Ratulangi Manado \\ ${ }^{3}$ Bagian Ortodonsia Program Studi Kedokteran Gigi Fakultas Kedokteran \\ Universitas Sam Ratulangi Manado \\ Email: aves.ardheansa@yahoo.com
}

\begin{abstract}
The habit is a repeated pattern of behavior. Habits that occur in the oral cavity is also known as oral habit and naturally occur in less than six years of age. Oral habits might happen to more than six years of age that can lead to abnormalities in the structure of dento-facial. Persistent oral habits may be due to dysfunction and psychological disorders. Attention is needed to prevent oral habit continued. The purpose of this study was to obtain an overview of oral habits at a Catholic Elementary School II St. Anthony Palu students. This type of research used is descriptive study and sampling conducted by the proportional approach of simple random sampling. Data on oral description habit obtained by filling out the questionnaire by the parents / guardians of students. The number of samples in this study are 137 students. The results find that 52 students (38\%) had oral habit. Distribution of the types of oral habits shows that four students $(7,7 \%)$ have thumb sucking habit, 21 students $(40,4 \%)$ have nail biting habit, 10 students $(19,2 \%)$ have lip sucking habit, 14 students (27\%) have tongue thrusting habit, and 21 students $(40,4 \%)$ have mouth breathing habit. Boys students have oral habits more than the girl students. An eight-year age group has the most oral habits. Government health agencies in this regard would be able to carry out socialization practices especially regarding oral habits that can affect dento-facial structures.
\end{abstract}

Key word: Oral habits.

Abstrak: Kebiasaan merupakan suatu pola perilaku yang diulangi. Kebiasaan dapat terjadi didalam rongga mulut yang disebut juga sebagai oral habit dan wajar terjadi pada usia kurang dari enam tahun. Oral habit dapat berlanjut pada usia lebih dari enam tahun yang dapat menyebabkan kelainan pada struktur dento-fasial. Oral habit yang berlanjut tersebut dapat dikarenakan adanya kelainan fungsi tubuh dan gangguan psikologis. Perhatian sangat dibutuhkan untuk mencegah timbulnya oral habit yang berlanjut. Tujuan dari penelitian ini adalah untuk mendapatkan gambaran oral habit pada murid SD Katolik II St. Antonius Palu. Jenis penelitian yang digunakan yaitu penelitian deskriptif dan pengambilan sampel dilakukan dengan metode proportional simple random sampling. Pengambilan data mengenai gambaran oral habit didapat dengan cara pengisian kuesioner oleh orang tua/wali murid. Jumlah sampel dalam penelitian ini sebanyak 137 murid. Hasil penelitian mendapati bahwa 52 murid (38\%) memiliki oral habit. Distribusi jenis-jenis oral habit menunjukkan bahwa empat murid (7,7\%) murid memiliki kebiasaan menghisap ibu jari, 21 murid (40,4\%) memiliki kebiasaan menggigit kuku, 10 murid (19,2\%) memiliki kebiasaan menghisap bibir, 14 murid (27\%) memiliki kebiasaan mendorong lidah, dan 21 murid (40,4\%) memiliki kebiasaan bernafas melalui mulut. Murid-murid yang berjenis kelamin laki-laki memiliki oral habit lebih banyak dibandingkan 
dengan murid-murid yang berjenis kelamin perempuan. Kelompok usia delapan tahun merupakan yang paling banyak memiliki oral habit. Pemerintah dalam hal ini instansi kesehatan kiranya dapat melaksanakan sosialisasi mengenai kebiasaan-kebiasaan khususnya oral habit yang dapat mempengaruhi struktur dento-fasial.

Kata kunci: oral habit.

Kebiasaan merupakan suatu pola perilaku yang diulangi dan pada umumnya merupakan suatu tahap perkembangan yang normal yang terjadi secara alami dan kompleks. Setiap orang yang melakukan kebiasaan tersebut sering tidak mengenali perilaku kebiasaan tersebut. ${ }^{1-2}$

Kebiasaan dapat terjadi di dalam rongga mulut. Kebiasaan yang terjadi di dalam rongga mulut tersebut dapat mempengaruhi pola perkembangan struktur dento-fasial. Setiap kebiasaan yang terjadi di dalam rongga mulut dan dapat mempengaruhi pola perkembangan struktur dentofasial tersebut disebut sebagai oral habit. ${ }^{2-3}$

Oral habit sering terjadi pada anakanak dan bahkan terdapat oral habit yang dapat terjadi pada bayi dalam masa awal kehidupan. Oral habit tersebut dapat berupa menghisap ibu jari, menggigit kuku, menghisap bibir, mendorong lidah, dan bernafas melalui mulut. ${ }^{1}$

Oral habit merupakan sesuatu yang wajar terjadi pada anak usia kurang dari enam tahun dan dapat berhenti dengan sendirinya pada anak usia kurang dari enam tahun. Apabila oral habit tersebut masih berlanjut setelah usia enam tahun, maka akan menyebabkan kelainan pada struktur dento-fasial seperti maloklusi, kelainan pada bentuk wajah, dan kelainan pada bentuk palatum. ${ }^{1,4-5}$

Oral habit yang masih berlanjut pada anak usia lebih dari enam tahun dapat disebabkan oleh adanya suatu kelainan fungsi tubuh dan juga gangguan psikis akibat stres emosional yang terjadi akibat tekanan psikis. Perhatian orang tua sangat dibutuhkan untuk dapat mencegah timbulnya oral habit yang berlanjut tersebut. ${ }^{4-5}$

Usia lebih dari enam tahun merupakan usia anak memasuki masa sekolah dasar. Anak yang telah memasuki sekolah dasar akan dihadapkan pada pergaulan dengan teman-temannya di sekolah serta masalah mengenai pelajaran dan tekanan dari guru. Perhatian serta cara orang tua mendidik dan membina anak akan mempengaruhi perilaku anak di sekolah. Kurangnya perhatian orang tua akan mempengaruhi keadaan psikis anak yang dapat mendorong anak untuk melakukan oral habit. ${ }^{6}$

Perhatian orang tua juga sangat dibutuhkan pada anak yang berusia lebih dari enam tahun untuk dapat memperhatikan suatu kelainan fungsi tubuh seperti adanya polip nasopharyngeal dan alergi yang dapat menyebabkan oral habit. Apabila orang tua kurang memperhatikan kelainan fungsi tubuh anak yang dapat menimbulkan terjadinya oral habit tersebut, maka anak akan terus melakukan oral habit tersebut sehingga dapat mempengaruhi perkembangan struktur dento-fasial anak.

Survei menunjukkan bahwa 80\% masyarakat Indonesia mengalami maloklusi. ${ }^{7}$ Maloklusi merupakan kelainan gigi yang menduduki urutan kedua kelainan gigi terbanyak di Indonesia yang salah satu faktor penyebabnya ialah oral habit. ${ }^{7,8}$ Prevalensi oral habit sendiri di beberapa tempat masih cukup tinggi. Onyeaso ${ }^{9}$ pada tahun 2004 menemukan bahwa dari 493 anak usia tujuh sampai 10 tahun di Nigeria, 9,9\% diantaranya melakukan oral habit. Pada tahun 2009 Bhayya dan Shyagali ${ }^{10}$ menemukan, dari 1000 anak usia 11-13 tahun di India, 38\% diantaranya melakukan oral habit. Penelitian yang dilakukan oleh Winny dan Eriska ${ }^{6}$ pada anak usia enam sampai 12 tahun di Sekolah Dasar Laboratorium Percontohan Universitas Pendidikan Indonesia Kampus Cibiru Bandung pada tahun 2007 menemukan bahwa dari 617 anak didapati 223 atau 36,14\% anak memiliki oral habit.

Penelitian ini bertujuan untuk mengetahui gambaran oral habit dan secara khusus untuk mengetahui distribusi jenis-jenis oral habit pada murid SD Katolik II St. Antonius 
Palu. SD Katolik II St. Antonius Palu berada di wilayah kota Palu provinsi Sulawesi Tengah. Provinsi Sulawei Tengah sendiri belum pernah dilakukan suatu penelitian mengenai kesehatan gigi dan mulut. SD Katolik II St. Antonius Palu merupakan salah satu sekolah dasar yang memiliki biaya pendidikan yang cukup tinggi, sehingga memiliki murid yang berasal dari keluarga yang berkecukupan dengan kesi-bukan yang tinggi sehingga memungkinkan kurangnya perhatian orang tua terhadap anak-anak mereka dan dapat mempengaruhi perilaku anak serta hubungan sosial anak di sekolah sehingga dapat mendorong timbulnya oral habit.

\section{METODE PENELITIAN}

Penelitian ini merupakan penelitian deskriptif. Besar sampel yang diteliti berjumlah 137 murid yang dihitung berdasarkan rumus Slovin dengan teknik pengambilan sampel menggunakan proportional simple random sampling.

Penelitian dilakukan dengan terlebih dahulu meminta izin untuk melakukan penelitian pada Kepala SD Katolik II St. Antonius Palu. Pengambilan data dilakukan dengan menggunakan kuesioner yang disi oleh orang tua/wali murid dengan meminta izin terlebih dahulu kepada orang tua/wali murid melalui informed consent. Pemberian informed consent dan kuesioner kepada orang tua/wali murid dilakukan melalui murid SD Katolik II St. Antonius Palu. Kuesioner yang telah diisi oleh orang tua/ wali murid, kemudian dikembalikan melalui murid SD Katolik II St. Antonius Palu.

Pengambilan data sekunder berupa usia dan jenis kelamin murid diambil dengan melihat data profil sekolah SD Katolik II St. Antonius Palu. Data yang didapat kemudian diolah berdasarkan distribusi frekuensi dan disajikan dalam bentuk diagram batang lalu dianalisis berdasarkan hasil persentase.

\section{HASIL PENELITIAN}

\section{Karakteristik subjek penelitian}

Subjek penelitian ini berjumlah 137 murid, terdiri dari murid-murid berjenis kelamin laki-laki dan perempuan yang dapat dilihat pada Gambar 1.

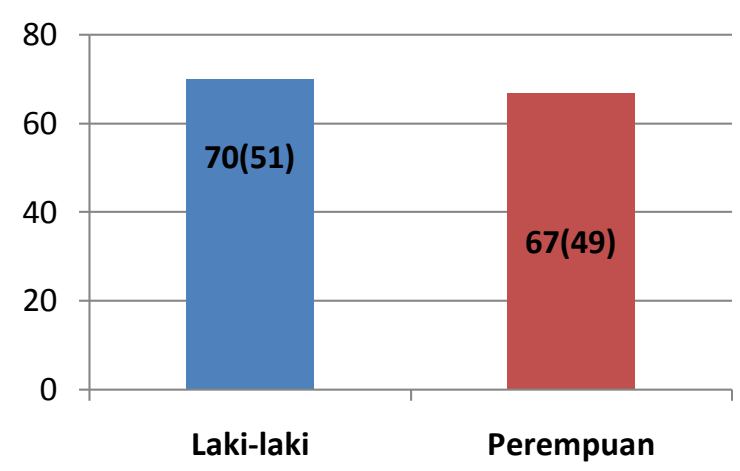

Keterangan: ( \% )

Gambar 1. Distribusi subjek penelitian berdasarkan jenis kelamin.

Data pada Gambar 1. menunjukkan bahwa subjek penelitian yang berjenis kelamin laki-laki jumlahnya lebih banyak yaitu sebanyak 70 murid (51\%) dibandingkan subjek penelitian yang berjenis kelamin perempuan yang berjumlah sebanyak 67 murid (49\%).

Subjek penelitian pada penelitian ini dapat dikelompokkan berdasarkan usia (Gambar 2.).

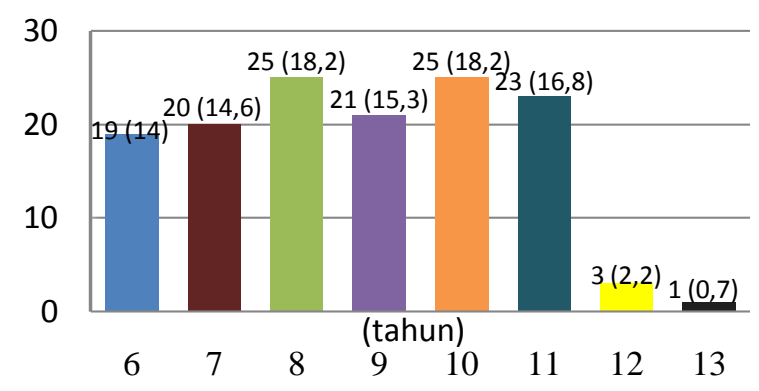

Keterangan: ( \% )

Gambar 2. Distribusi subjek penelitian berdasarkan usia.

Data pada Gambar 2. menunjukkan bahwa kelompok usia delapan tahun dan 10 tahun merupakan kelompok usia yang jumlahnya paling banyak dalam penelitian ini yaitu masing-masing sebanyak 25 murid (18,2\%). Kelompok usia 12 tahun dan 13 tahun merupakan kelompok usia yang jumlahnya paling sedikit dalam penelitian 
ini yaitu masing-masing sebanyak tiga murid $(2,2 \%)$ dan satu murid $(0,7 \%)$.

\section{Hasil penelitian gambaran oral habit}

Hasil penelitian mengenai gambaran oral habit di SD Katolik II St. Antonius Palu didapati tidak semua subjek penelitian memiliki oral habit (Gambar 3.).

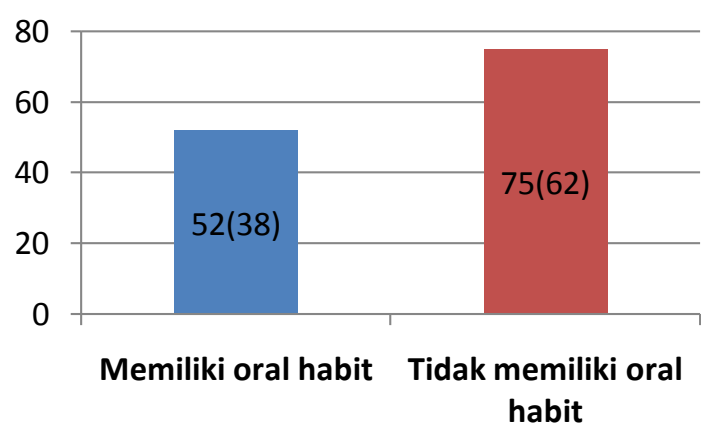

Keterangan: ( \% )

Gambar 3. Distribusi subjek penelitian yang memiliki oral habit dan yang tidak memiliki oral habit pada seluruh subjek penelitian.

Data pada Gambar 3 menunjukkan bahwa subjek penelitian yang tidak memi-liki oral habit jumlahnya lebih banyak yaitu 75 murid (62\%) daripada subjek penelitian yang memiliki oral habit yaitu sebanyak 52 murid (38\%).

Subjek penelitian yang memiliki oral habit pada penelitian ini dapat dikelompokkan berdasarkan jenis kelamin (Gambar 4).

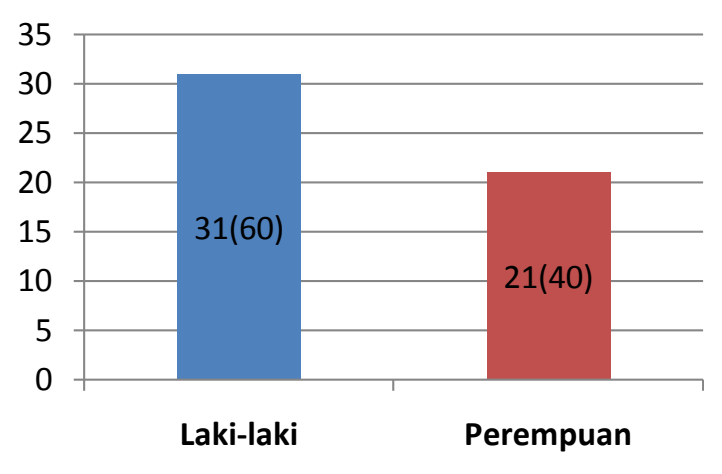

Keterangan: ( \% )

Gambar 4. Distribusi subjek penelitian yang memiliki oral habit berdasarkan jenis kelamin.
Data pada Gambar 4. menunjukkan bahwa subjek penelitian yang berjenis kelamin laki-laki yang memiliki oral habit jumlahnya lebih banyak yaitu sebanyak 31 murid (60\%) daripada subjek penelitian yang berjenis kelamin perempuan yang memiliki oral habit yaitu sebanyak 21 murid (40\%).

Subjek penelitian yang memiliki oral habit pada penelitian ini dapat dikelompokkan berdasarkan usia (Gambar 5).

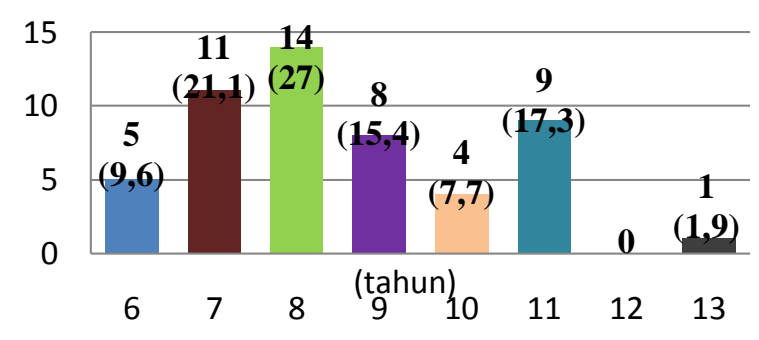

Keterangan: ( \% )

Gambar 5. Distribusi subjek penelitian yang memiliki oral habit berdasarkan usia.

Data pada Gambar 5. menunjukkan bahwa subjek penelitian yang memiliki oral habit paling banyak terdapat pada kelompok usia delapan tahun yaitu sebanyak 14 murid (27\%). Data pada Gambar 5. juga menunjukkan bahwa pada kelompok usia 12 tahun tidak terdapat subjek penelitian yang memiliki oral habit.

Subjek penelitian yang memiliki oral habit dapat dibedakan berdasarkan jumlah kebiasaan yang dimiliki (Gambar 6).

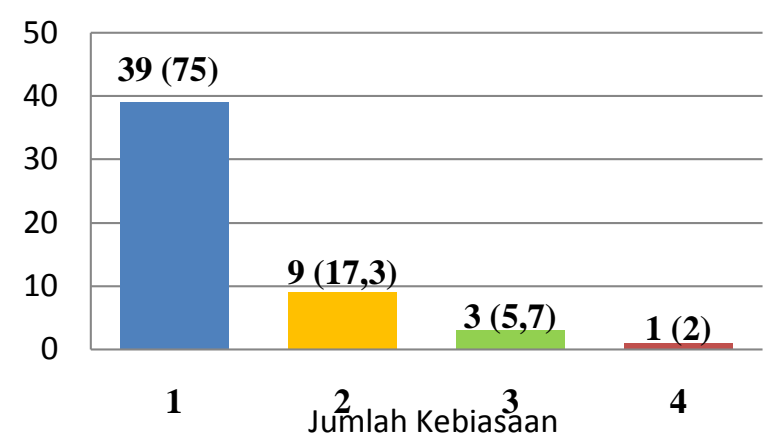

Keterangan: ( \% )

Gambar 6. Distribusi subjek penelitian yang memiliki oral habit berdasarkan jumlah kebiasaan yang dimiliki. 
22 Jurnal e-GiGi (eG), Volume 1, Nomor 1, Maret 2013, hlm. 18-27

Data pada Gambar 6. menunjukkan bahwa sebagian besar subjek penelitian dengan oral habit hanya memiliki satu kebiasaan yaitu sebanyak 39 murid (75\%), sedangkan sembilan murid $(17,3 \%)$ memiliki dua kebiasaan, tiga murid (5,7\%) memiliki tiga kebiasaan, dan satu murid (2\%) memiliki empat kebiasaan.

\section{Distribusi jenis-jenis oral habit}

Penelitian untuk mengetahui gambaran oral habit meliputi ditribusi jenis-jenis oral habit yang terdiri dari kebiasaan menghisap ibu jari, menggigit kuku, menghisap bibir, mendorong lidah, dan bernafas melalui mulut. Distribusi jenis-jenis oral habit pada seluruh subjek penelitian yang memiliki oral habit dapat dilihat pada Gambar 7.

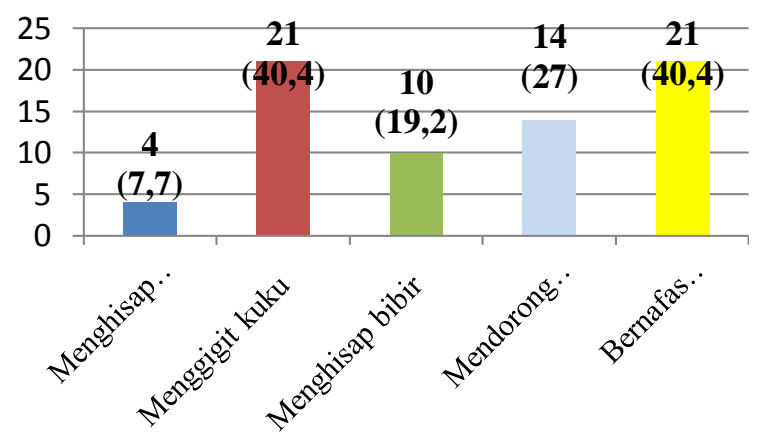

Keterangan: (\%)

Gambar 7. Distribusi jenis-jenis oral habit pada seluruh subjek penelitian yang memiliki oral habit.
Data pada Gambar 7. menunjukkan bahwa menggigit kuku dan bernafas melalui mulut merupakan kebiasaan yang paling banyak dimiliki pada seluruh subjek penelitian yang memiliki oral habit yaitu masing-masing sebanyak 21 murid (40,4\%). Jumlah kebiasaan menghisap ibu jari merupakan yang paling sedikit dimiliki pada seluruh subjek penelitian yang memiliki oral habit yaitu hanya sebanyak empat murid (7,7\%).

Distribusi jenis-jenis oral habit pada seluruh subjek penelitian yang memiliki oral habit dapat dikelompokkan berdasarkan usia (Gambar 8).

Data pada Gambar 8. menunjukkan bahwa tidak terdapat kebiasaan menghisap ibu jari pada kelompok usia diatas usia delapan tahun. Jumlah kebiasaan menggigit kuku paling banyak pada kelompok usia sembilan tahun yaitu sebanyak lima murid (62,5\%) dan kelompok usia 11 tahun sebanyak lima murid (55,5\%). Tidak terdapat perbedaan jumlah yang mencolok pada kebiasaan menghisap bibir pada kelompok usia enam tahun sampai kelompok usia 10 tahun, kemudian jumlahnya menjadi lebih banyak pada kelompok usia 11 tahun yaitu sebanyak tiga murid (33,3\%). Kebiasaan mendorong lidah jumlahnya paling banyak pada kelompok usia tujuh tahun yaitu sebanyak enam murid (54,5\%). Kebiasaan bernafas melalui mulut jumlahnya paling banyak pada kelompok usia delapan tahun yaitu sebanyak delapan murid

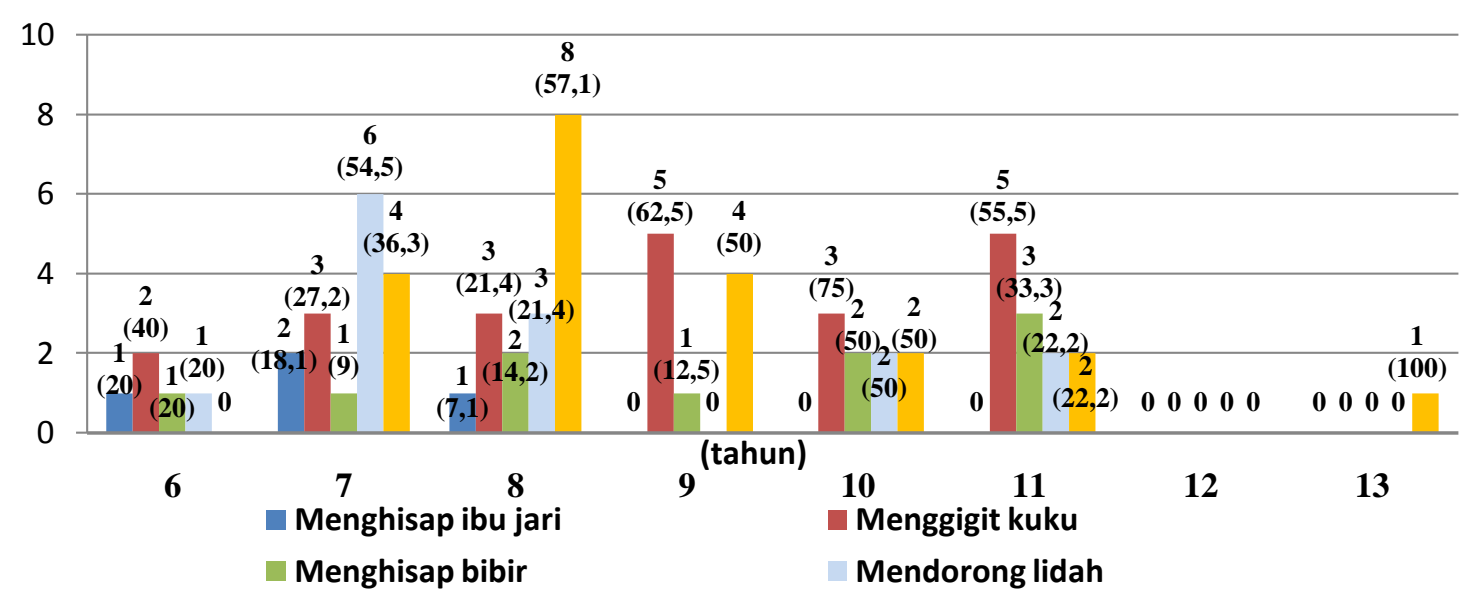

Keterangan: ( \% )

Gambar 8. Distribusi jenis-jenis oral habit berdasarkan usia. 
Keterangan: ( \% )

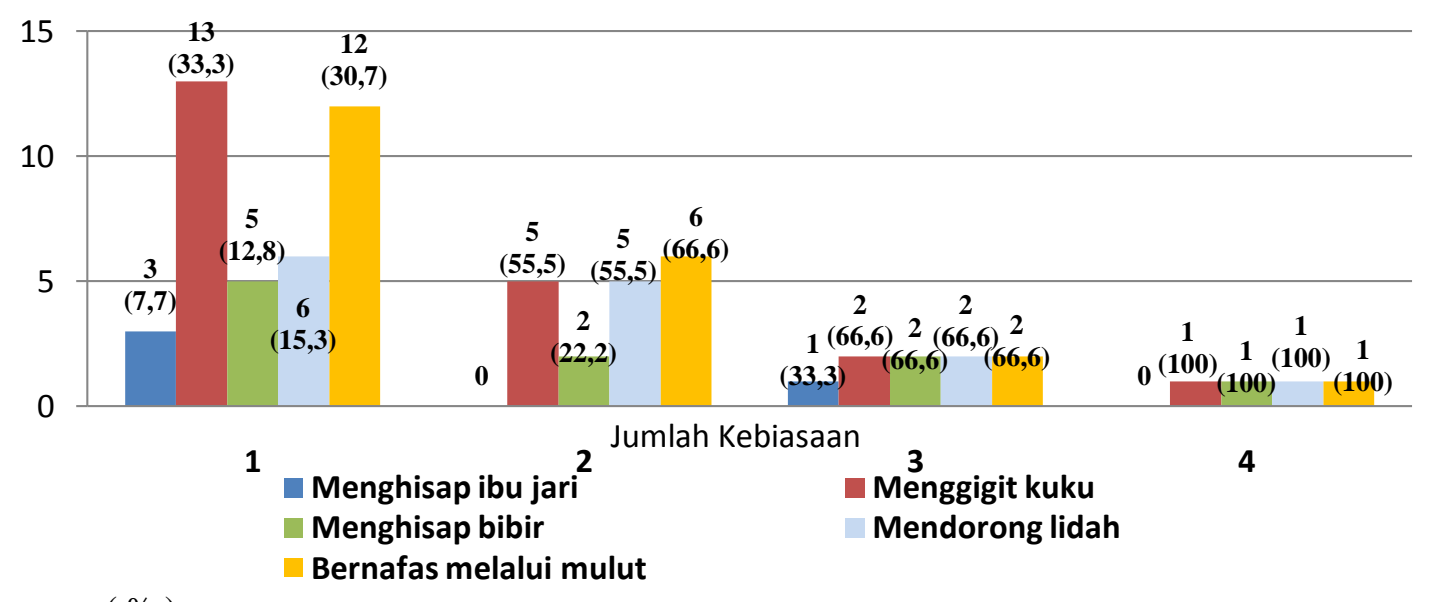

Gambar 9. Distribusi jenis-jenis oral habit pada subjek penelitian yang memiliki oral habit berdasarkan jumlah kebiasaan yang dimiliki.

(57,1\%), namun kebiasaan bernafas melalui mulut juga masih dijumpai pada kelompok usia 13 tahun sebanyak satu murid (100\%). Tidak terdapat oral habit pada kelompok usia 12 tahun.

Distribusi jenis-jenis oral habit pada subjek penelitian yang memiliki oral habit pada penelitian ini dapat dibedakan berdasarkan jumlah kebiasaan yang dimiliki (Gambar 9).

Data pada Gambar 9 menunjukkan bahwa menggigit kuku merupakan kebiasaan yang paling banyak dimiliki oleh subjek penelitian dengan satu kebiasaan yaitu sebanyak 13 murid (33,3\%). Semua jenis oral habit jumlahnya semakin sedikit pada subjek penelitian dengan dua kebiasaan, tiga kebiasaan, dan empat kebiasaan.

\section{BAHASAN}

Subjek penelitian yang berjenis kelamin laki-laki pada penelitian ini lebih banyak dibandingkan dengan subjek penelitian yang berjenis kelamin perempuan. Hal tersebut dikarenakan murid-murid di SD Katolik II St. Antonius Palu memang lebih banyak yang berjenis kelamin laki-laki daripada yang berjenis kelamin perempuan.

Berdasarkan usia, jumlah subjek penelitian yang paling banyak pada penelitian ini terdapat pada kelompok usia delapan tahun dan 10 tahun (Gambar 2.). Hal ini dikarenakan usia delapan tahun paling banyak dijumpai pada murid kelas tiga, namun usia delapan tahun juga terdapat pada kelas satu, kelas dua, dan kelas empat sehingga dalam pengambilan sampel secara proportional simple random jumlahnya paling banyak pada penelitian ini. Usia 10 tahun merupakan usia yang paling banyak terdapat pada murid kelas lima di SD Katolik II St. Antonius Palu. Kelas lima sendiri merupakan kelas yang memiliki murid paling banyak di SD Katolik II St. Antonius Palu.

Hasil penelitian mengenai gambaran oral habit di SD Katolik II St. Antonius Palu didapati sebanyak 52 murid (38\%) memiliki oral habit (Gambar 3.). Persentase hasil penelitian ini sama dengan yang didapat oleh Bhayya dan Shyagali pada penelitian mereka di India pada tahun 2009 terhadap anak berusia 11-13 tahun. Bhayya dan Shyagali $^{5}$ mendapatkan jumlah persentase sebesar 38\%. Persentase hasil penelitian ini juga hampir sama dengan yang didapat oleh Winny dan Eriska ${ }^{6}$ pada anak berusia enam sampai 12 tahun di Sekolah Dasar Laboratorium Percontohan Universitas Pendidikan Indonesia Kampus Cibiru Bandung pada tahun 2007 dengan jumlah persentase $36,14 \%$. Beberapa penelitian diatas memiliki persamaan dengan penelitian ini dalam hal sampel. Sampel pada beberapa penelitian tersebut merupakan anak-anak perkotaan dan memiliki usia yang tergolong usia sekolah dasar dan usia yang 
dapat menimbulkan kelainan dento-fasial apabila terdapat oral habit. ${ }^{6,10}$

Anak-anak yang bersekolah di SD Katolik II St. Antonius Palu berasal dari keluarga yang berkecukupan yang mayoritas orang tua mereka bekerja sebagai pegawai swasta, wiraswata dan pegawai negeri sipil. Masing-masing orang tua mereka dihadapkan dengan kesibukan dengan pekerjaan yang dapat mempengaruhi kurangnya perhatian kepada anak-anak mereka. Kurangnya perhatian orang tua pada anakanak dapat mempengaruhi prilaku anak di sekolah dalam hubungan sosial anak pada teman-temannya dan dapat mempengaruhi keadaan psikologis anak. $^{11,12}$

Jhonson dan Larson $^{13}$ menyimpulkan bahwa suatu kebiasaan yang berlanjut adalah suatu hasil yang didasari permasalahan emosional dan psikologis. Oral habit yang berlanjut juga berhubungkan dengan keadaan emosi dan psikis. Oral habit juga dapat disebabkan oleh adanya kelainan fungsi tubuh seperti adanya polip nasopharyngeal, alergi, rhinitis atrofi dan yang berhubungan terhadap kesehatan umum anak. ${ }^{4-5,13}$

Secara umum, penelitian ini mendapatkan bahwa murid berjenis kelamin laki-laki lebih banyak yang memiliki oral habit dibandingkan murid berjenis kelamin perempuan yaitu sebanyak 31 murid (48,6\%) laki-laki memiliki oral habit dan 21 murid (26,9\%) perempuan memiliki oral habit (Gambar 4.). Hal ini mungkin disebabkan karena anak laki-laki merupakan anak yang cenderung melawan tuntutan. Kekeliruan orang tua selama pendidikan dan pengawasan anak-anak mereka akan meyebabkan anak-anak mereka mengalami gangguan secara psikis dan mental yang dapat mengganggu keadaan psikologis anak tersebut sehingga dapat mendorong timbulnya oral habit khususnya pada kebiasaan menghisap ibu jari, menggigit kuku, dan bernafas melalui mulut. ${ }^{1,4-5}$

Kelompok usia delapan tahun merupakan kelompok usia yang secara umum paling banyak memiliki oral habit pada penelitian ini yaitu sebanyak 14 murid (56\%) (Gambar 5.). Hal ini mungkin disebabkan karena usia delapan tahun merupakan usia anak mulai menjalin persahabatan. Banyak dalam pergaulan sekarang ini membawa dampak negatif bagi anak, dampak negatif tersebut bisa mengakibatkan gangguan psikologis pada anak yang dapat mendorong timbulnya oral habit. $^{5,11}$

Oral habit merupakan suatu tindakan berulang dengan berbagai jenis cara dalam melakukannya. Hasil penelitian pada penelitian ini menemukan bahwa sebagian besar atau sebanyak 39 murid (75\%) subjek penelitian yang memiliki oral habit hanya melakukan satu kebiasaan (Gambar 6.). Hal ini mungkin disebabkan karena sebagian besar subjek penelitian yang memiliki satu kebiasaan hanya memiliki satu penyebab terjadinya oral habit yaitu berkaitan dengan keadaan psikologis. Distribusi jenis-jenis oral habit berdasarkan jumlah kebiasaan yang dimiliki pada penelitian ini menunjukkan bahwa kebiasaan menggigit kuku merupakan yang paling banyak dimiliki oleh subjek penelitian yang hanya memiliki satu kebiasaan yaitu sebanyak 13 murid (33,3\%) (Gambar 8.). Menggigit kuku merupakan jenis oral habit yang penyebabnya hanya berkaitan dengan keadaan psikologis anak. ${ }^{4,14}$

Distribusi jenis-jenis oral habit pada penelitian ini meliputi kebiasaan menghisap ibu jari, menggigit kuku, menghisap bibir, mendorong lidah, dan bernafas melalui mulut. Hasil penelitian ini menemukan bahwa kebiasaan menggigit kuku dan kebiasaan bernafas melalui mulut merupakan yang paling banyak yaitu masingmasing sebanyak 21 murid (40,4\%) (Gambar 7).

Kebutuhan untuk menggigit dan bahkan untuk menggigit kuku jari tangan berhubungan dengan suatu ketegangan psikoemosional. Berdasarkan kuesioner yang diisi oleh orang tua/wali murid didapati juga bahwa murid-murid yang memiliki lebih dari satu kebiasaan lebih sering melakukan kebiasaan menggigit kuku daripada kebiasaan yang lain. Pergaulan dengan temanteman di sekolah, adanya tuntutan dan tata tertib di sekolah dapat mempengaruhi 
psikologi anak. Bagi anak yang hidup agak longgar dari peraturan tata tertib dalam keluarga, akan bereaksi negatif terhadap peraturan tata tertib tersebut yang oleh Freud disebut sebagai frustasi. ${ }^{12,14}$

Beberapa studi yang dikutip oleh Jefferson menunjukkan bahwa anak-anak dengan kebiasaan bernafas melalui mulut disebabkan antara lain kelelahan di sekolah dan mungkin adanya masalah di sekolah. Kebiasaan bernafas melalui mulut juga sering dihubungkan dengan kebiasaan mendorong lidah. Berdasarkan usia, kebiasaan mendorong lidah paling banyak terdapat pada kelompok usia tujuh tahun yaitu sebanyak enam murid (54,5\%) (Gambar 8.). Kebiasaan bernafas melalui mulut paling banyak pada kelompok usia delapan tahun yaitu sebanyak delapan murid (57,1\%) (Gambar 8.). Hal ini mungkin disebabkan karena anak yang mulai merasakan adanya persaingan di sekolah terutama dalam hal berolahraga. Usia tujuh tahun dan delapan tahun merupakan usia anak yang secara personal-sosial mulai menikmati suatu permainan dan kelompok olahraga. ${ }^{4,12,15-16}$

Kebiasaan mendorong lidah dan kebiasaan bernafas melalui mulut juga berkaitan dengan adanya kelainan-kelainan pada tubuh. Kelainan-kelainan tersebut seperti tonsillitis, faringitis, penyumbatan jalan nafas, dan polip nasopharyngeal. ${ }^{4}$

Kebiasaan bernafas melalui mulut pada penelitian ini jumlahnya lebih sedikit pada kelompok usia diatas usia delapan tahun (Gambar 8.). Hal ini mungkin disebabkan karena anak-anak yang berusia lebih dari delapan tahun lebih sering melakukan kegiatan membaca, membuat artikel, dan mencari informasi yang bermanfaat daripada kegiatan berolahraga yang dapat menimbulkan kelelahan dan dapat mendorong terjadinya kebiasaan bernafas melalui mulut. $^{15-16}$

Hasil penelitian ini mendapati 100\% anak pada kelompok usia 13 tahun memiliki kebiasaan bernafas melalui mulut, namun pada usia 13 tahun tersebut hanya terdapat satu subjek penelitian (Gambar 5 dan 8.). Hal ini mungkin disebabkan anak tersebut memiliki masalah di sekolah sehingga anak tersebut tidak naik kelas karena usia sekolah dasar sendiri meliputi usia enam sampai 12 tahun. Gangguan psikomatis dapat terjadi karena seorang anak yang mengalami frustasi yang dapat menyebabkan timbulnya suatu penyakit tubuh. Kebiasaan bernafas melalui mulut sendiri berkaitan dengan suatu kelainan fungsi tubuh yang dialami oleh anak. Adanya kelainan anatomi tubuh misalnya kelainan pada nasal septum dapat menyebabkan anak sulit untuk bernafas sehingga juga dapat menimbulkan kebiasaan bernafas melalui mulut. ${ }^{4,12,15}$

Seorang anak yang memiliki kebiasaan menghisap ibu jari akan mengalami masa transisi ke kebiasaan menggigit kuku. ${ }^{4}$ Hasil penelitian ini menemukan bahwa jumlah kebiasaan menghisap ibu jari lebih sedikit dan bahkan tidak terdapat kebiasaan menghisap ibu jari pada kelompok usia diatas usia delapan tahun (Gambar 8.). Hal ini mungkin terjadi karena anak yang memiliki kebiasaan menghisap ibu jari telah mengganti kebiasaan menghisap ibu jari menjadi kebiasaan menggigit kuku.

Kebiasaan menghisap bibir dapat terjadi karena secara psikologis anak akan merasakan kenyamanan dalam melakukannya. Kebiasaan menghisap bibir sendiri berhubungan dengan psikologis anak. Hasil penelitian ini menemukan bahwa kebiasaan menghisap bibir mengalami peningkatan jumlah paling banyak pada kelompok usia 11 tahun yaitu sebanyak tiga murid (33,3\%) (Gambar 8.). Hal ini mungkin terjadi karena pada usia 11 tahun anak mulai merasakan pentingnya pertemanan. Dalam lingkungan sekolah dasar, anak yang populer dapat dengan mudah mendapat teman. Anak yang pemalu atau kurang percaya diri dapat menyebabkan anak menjadi tidak populer dan kurang mendapat perhatian dari teman. Rasa kurang percaya diri tersebut sering mempengaruhi psikologis anak dan dapat menyebabkan anak melakukan kebiasaan menghisap bibir., ${ }^{5,11}$

Usia 12 tahun pada penelitian ini tidak terdapat murid yang memiliki oral habit (Gambar 8.). Hal ini mungkin dikarenakan pada usia 12 tahun merupakan usia akhir 
masa anak-anak. Masalah psikologis merupakan salah satu penyebab oral habit. Dalam fase ini, anak mulai dapat berbagi pikiran dan perasaan dengan temannya sehingga anak dapat berbagi perasaan terhadap masalah psikologi yang sedang dialami. ${ }^{4,11-12}$

Berdasarkan jumlah kebiasaan yang dimiliki, seluruh jenis oral habit jumlahnya semakin sedikit mulai dari yang memiliki dua kebiasaan hingga yang memiliki empat kebiasaan (Gambar 9.). Hal ini mungkin disebabkan karena jumlah anak yang memiliki lebih dari satu kebiasaan juga semakin menurun mulai dari yang memiliki dua kebiasaan hingga yang memiliki empat kebiasaan. Dapat diasumsikan bahwa anakanak yang melakukan lebih dari satu kebiasaan memiliki suatu kelainan fungsi tubuh dan mungkin adanya kelainan anatomi seperti pada kebiasaan bernafas melalui mulut dan juga memiliki suatu masalah psikologis. Semakin banyak jumlah kebiasaan yang dilakukan oleh anak maka semakin banyak pula masalah yang dialami oleh anak sebagai penyebab oral habit. Berbeda dengan yang hanya melakukan satu kebiasaan yang mayoritas hanya disebabkan oleh satu masalah yaitu masalah psikologis. ${ }^{4,14}$

Persentase distribusi jenis-jenis oral habit pada penelitian ini tidak mendapatkan hasil $100 \%$ apabila dijumlahkan. Hal ini dikarenakan pada penelitian ini terdapat subjek penelitian yang memiliki jenis-jenis oral habit lebih dari satu.

\section{SIMPULAN}

Berdasarkan hasil penelitian gambaran oral habit pada murid SD Katolik II St. Antonius Palu , dapat disimpulkan:

1. Terdapat sebanyak 52 murid (38\%) memiliki oral habit, sebagian besar murid-murid yang memiliki oral habit yaitu sebanyak 39 murid (75\%) hanya melakukan satu kebiasaan dan muridmurid yang berjenis kelamin laki-laki memiliki oral habit lebih banyak dibandingkan dengan murid-murid yang berjenis kelamin perempuan yaitu sebanyak 31 murid (60\%).

2. Usia delapan tahun merupakan kelompok yang paling banyak memiliki oral habit yaitu sebanyak 14 murid (56\%).

3. Menggigit kuku dan bernafas melalui mulut merupakan kebiasaan yang jumlahnya paling banyak yaitu masingmasing sebanyak 14 murid (40,4\%).

4. Menghisap ibu jari merupakan kebiasaan yang jumlahnya paling sedikit yaitu hanya sebanyak empat murid (7,7\%).

\section{DAFTAR PUSTAKA}

1. Gildasya, Riyanti E, Hidayat S. Prevalence of oral habits in homeless children undercare of Yayasan Bahtera Bandung. Riset. Bandung: Faculty of Dentistry Padjajaran University; 2007.p.2. Available from URL:http://resources. unpad.ac.id/unpad.content/uploads/publikas i_dosen/Prevalence\%20of\%20oral\%20habi ts\%20in\%20homeless\%20children\%20und er\%20care\%of.pdf.

2. Suwwon YI. Longitudinal effect of habitbreaking appliances on tongue and dentoalveolar relations and speech in children with oral habit. Thesis. Toronto: Faculty of Dentistry University of Toronto, 2008; p.14,33,36.

3. Phulari BS. Orthodontics principles and practice. New Delhi: JP Medical Ltd, 2011; p.264.

4. Gartika M. The effect of oral habits in the oral cavity of children and its treatment. Padj J Dent. 2008;20(2):124,126-7.

5. Laksmiastuti RS. Pemakaian lib bumper pada anak-anak dengan kebiasaan jelek menggigit bibir bawah dan menghisap ibu jari. Denta J. 2007;1(2):90-1,93-4.

6. Winny Y, Eriska R. Gambaran oral habit pada anak usia 6-12 tahun di Sekolah Dasar Laboratorium Percontohan Universitas Pendidikan Indonesia Kampus Cibiru Bandung [Skripsi]. Bandung: Fakultas Kedokteran Gigi Universitas Padjadjaran; 2007.

7. Dewi O. Analisis hubungan maloklusi dengan kualitas hidup pada remaja SMU kota Medan tahun 2007 [Tesis]. Medan: Program pascasarjana Universitas Sumatera Utara; 2008.

8. Rohmah F, Netiani E, Taqwin A. Hubungan lebar mesiodistal gigi terhadap kecembungan profil jaringan lunak pada 
populasi cina. Jember: Fakultas Kedokteran Gigi Universitas Jember. [homepage on the Internet]. 2011. Available from URL: http://dentosca. wordpress.com/2011/04/08/artikel-1/

9. Onyeaso OC. Oral habits among 7-10 year-old school children in Ibadan. Nigeria. E Afr Med J. 2004;81:16.

10. Bhayya PD, Shyagali RT. Prevalence of oral habit in 11-13 year-old school children in Gulbarga city, India [serial online]. 2009 [cited??];8(3):1. Available from URL: http://www.vjo.it/read.php?fileoralhab.pdf

11. Nirwana AB. Psikologi bayi, balita, dan anak. Yogyakarta: Nuha Medika, 2011; p.116-28.
12. Soejanto A. Psikologi perkembangan. Cetakan kedelapan. Jakarta: Rineka Cipta, 2005; p.107-25.

13. Bishara SE. Textbook of Orthodontics. Philadelphia: Elsevier; 2001; p.251.

14. Tanaka MO, Vitral FW, Tanaka YG, Guerrero PA, Camargo SE. Nailbiting or onychophagia: A special habit. Am J Ort Dentfac Orthoped. 2008;134(2):305-8.

15. Jefferson $Y$. Mouth breathing adverse effect on facial growth, health, academics, and behavior. Academy of General Dentistry. 2010:19,20.

16. Adriana D. Tumbuh kembang dan terapi bermain pada anak. Jakarta: Salemba Medika, 2011; p.88-91. 